\title{
PENGARUH LIQUIDITAS, PROFITABILITAS, LEVERAGE DAN COVERAGE RATIO TERHADAP PERINGKAT OBLIGASI (STUDI KASUS PADA PERUSAHAAN PERBANKAN YANG TERDAFTAR DI BEI DAN PT. PEFINDO)
}

\author{
Ahmad Ardi Kurniawan ${ }^{1}$, Gendro Wiyono ${ }^{2}$, Risal Rinofah ${ }^{3}$ \\ Fakultas Ekonomi Universitas Sarjanawiyata Tamansiswa Yogyakarta \\ Email: bankai.hyourinmaru@,rocketmail.com
}

\begin{abstract}
Intisari
Penelitian ini bertujuan untuk mengetahui (1) pengaruh likuiditas yang diukur dengan current ratio terhadap peringkat obligasi (2) pengaruh profitabilitas yang diukur dengan return on asset terhadap peringkat obligasi (3) pengaruh leverage yang diukur dengan debt to equity ratio terhadap peringkat obligasi (4) pengaruh coverage ratio yang diukur dengan time interested earned terhadap peringkat obligasi. Penelitian ini menggunakan data sekunder. Populasi penelitian adalah perusahaan perbankan yang terdaftar di Bursa Efek Indonesia (BEI) dan PT Pemeringkat Efek Indonesia (PT Pefindo) pada periode 2014 sampai 2018 sejumlah 10 perusahaan. Teknik pengambilan sampel dengan teknik purposive sampling. Teknik analisis data menggunakan regresi logistik biner menggunakan alat analisis SPSS 23.
\end{abstract}

Kata Kunci: peringkat obligasi, current ratio, return on asset, debt to equity ratio, time interested earned.

\section{Abstract}

This study aims to determine (1) the effect of liquidity as measured by the current ratio of the bond rating (2) the effect of profitability as measured by return on assets to the bond rating (3) the effect of leverage as measured by the debt to equity ratio of the bond rating (4) the effect of coverage ratio measured by time interested earned on bond ratings. This research uses secondary data. The study population is a banking company listed on the Indonesia Stock Exchange (IDX) and PT Pemeringkat Efek Indonesia (PT Pefindo) in the 2014 to 2018 period of 10 companies. The sampling technique used was purposive sampling technique. Data analysis techniques using binary logistic regression using SPSS 23 analysis tools.

Keywords: bond rating, current ratio, return on asset, debt to equity ratio, time interested earned.

\section{PENDAHULUAN}

Dengan adanya obligasi di pasar modal sangat membantu baik bagi investor maupun perusahaan. Perusahaan dapat memperoleh dana melalui pasar modal dengan cara menjual obligasi kepada publik, lalu investor sebagai pihak yang memiliki dana dapat menggunakan pasar modal sebagai salah satu alternatif investasi untuk mendapatkan keuntungan. Setiap obligasi yang diperdagangkan di Bursa Efek Indonesia diwajibkan oleh Bapepam (Badan Pengawas Pasar Modal) oleh lembaga pemeringkat. Obligasi dapat dianalisis dengan menggunakan peringkat obligasi (bond rating). Peringkat obligasi (bond rating) merupakan kemampuan sebuah perusahaan dalam menyelesaikan kewajibannya dimasa mendatang. Peringkat obligasi ini sangat berguna untuk para calon investor yang ingin menanamkan modalnya dalam bentuk obligasi, karena investor dapat mengetahui sebesar apa keuntungan yang akan didapatkan dengan melihat peringkat obligasi yang akan dibeli.

Di Indonesia lembaga yang memiliki wewenang untuk memberi peringkat pada obligasi adalah PT Pemeringkat Efek Indonesia (PEFINDO), Sedangkan untuk pemeringkat obligasi internasional adalah Moody's and Standard \& Poor's (Darmadji \& Fakhruddin 2012). Likuiditas dihitung dengan membandingkan antara total aset lancar dengan total kewajiban 
lancar (Hery 2015). Dalam praktiknya, ada banyak manfaat yang dapat diperoleh dari perhitungan likuiditas, baik bagi pihak pemilik yaitu untuk digunakan sebagai alat untuk menilai kemampuan manajemen dalam mengelola dana yang telah dipercayakan termasuk dana yang digunakan untuk membayar kewajiban jangka pendek perusahaan, bagi pihak manajemen likuiditas yang digunakan untuk memantau ketersediaan jumlah kas khususnya dalam kaitannya dengan pemenuhann kewajiban yang akan segera jatuh tempo, bagi investor dapat bermanfaat untuk mengetahui tentang pembagian deviden tunai sedangkan untuk kreditor bermanfaat untuk mengetahui dan memperhitungkan pengembalian jumlah pokok pinjaman atau kredit yang akan diberikan.

Profitabilitas adalah salah satu rasio keuangan yang digunakan untuk melihat apakah perusahaan mampu dalam membayar hutang-hutang jangka pendeknya sehingga menggambarkan kemampuan perusahaan dalam menghasilkan laba melalui semua kemampuan dan sumber daya yang dimilikinya (Hery, 2015). Leverage merupakan kemampuan perusahaan dalam melunasi atau membayar semua pinjaman melalui jumlah aktiva yang dimiliki yang memengaruhi jenis - jenis laporan keuangan (Hery, 2015). Letak perbedaan antara leverage dan likuiditas terletak pada panjang waktu pinjamannya. Leverage mengukur kemampuan perusahaan untuk memenuhi kewajiban jangka panjang, sedangkan likuiditas mengukur kemampuan perusahaan untuk memenuhi kewajiban jangka pendek.

Coverage berfungsi sebagai salah satu ukuran kemampuan perusahaan untuk memenuhi pembayaran bunga sehingga dapat menghindari kebangkrutan (Horne \& Wachowicz, 2017). Secara umum, semakin tinggi rasionya, semakin besar kecenderungan perusahaan dapat membayar pembayaran bunganya tanpa kesulitan. Coverage juga menekankan pada kemampuan perusahaan untuk mengambil utang baru. Berdasarkan alasan - alasan tersebut, penulis tertarik untuk menjadikan penelitian dalam sebuah karya tulis ilmiah dalam bentuk jurnal yang berjudul "Pengaruh Liquiditas, Profitabilitas, Leverage dan Coverage Ratio Terhadap Peringkat Obligasi".

\section{TINJAUAN PUSTAKA DAN PENGEMBANGAN HIPOTESIS}

\section{Likuiditas}

Likuiditas yang diukur dengan current ratio adalah alat ukur yang digunakan untuk mengukur kemampuan perusahaan untuk mebayar kewajiban jangka pendeknya yang akan jatuh (Hery, 2015). Rasio ini menggambarkan tentang ketersediaan asset lancar yang dimiliki perusahaan untuk membayar kewajiban lancarnya. Oleh sebab itu, rasio lancar dapat diproyeksikan dengan rumus:

$$
\text { Current Ratio }=\frac{\text { Current Assets }}{\text { Current Liabilities }}
$$

\section{Profitabilitas}

Profitabilitas adalah salah rasio keuangan yang dapat digunakan untuk melihat kemampuan menghasilkan laba dengan memperhatikan tingkat penjualan, asset dan modal yang dimiliki oleh perusahaan Menurut (Hanafi \& Halim, 2016), formula Return On Assets (ROA) bisa dihitung dengan memperhitungkan elemen-elemen seperti:

\section{Leverage}

$$
\text { Return On Assets }(\mathrm{ROA})=\frac{\text { Laba bersih }+ \text { bunga }}{\text { Total Aset rata }- \text { rata }}
$$

Leverage atau solvabilitas adalah alat ukur untuk melihat kemampuan perusahaan dalam melunasi seluruh utang dengan memakai semua asset yang dimilikinya (Hery, 2015). Leverage yang diukur dengan Debt Equity Ratio (DER) dapat dihitung dengan 
memperhatikan elemen - elemen seperti berikut:

$$
\text { Debt to Equity Ratio }=\frac{\text { Total Liabillities }}{\text { Total Equity }}
$$

\section{Coverage}

Coverage berfungsi sebagai salah satu ukuran kemampuan perusahaan untuk memenuhi pembayaran bunga sehingga dapat menghindari kebangkrutan (Horne \& Wachowicz, 2017). Secara umum, semakin tinggi rasionya, semakin besar kecenderungan perusahaan dapat membayar pembayaran bunganya tanpa kesulitan. Coverage juga menekankan pada kemampuan perusahaan untuk mengambil utang baru. Dalam menilai risiko keuangan perusahaan, analisis keuangan pertama - tama harus menghitung rasio utang sebagai ukuran kasar dari risiko keuangan. Bergantung pada jadwal pembayaran utang dan rata - rata tingkat bunga, rasio utang dapat atau tidak dapat memberikan gambaran yang akurat aras kemampuan perusahaan untuk memenuhi liabilitas keuangannya. Oleh karena itu, kita melakukan argumentasi atas rasio utang dengan analisis rasio cakupan. Selain itu, kita menyadari bahwa pembayaran bunga dan prinsipal tidak benar - benar dipenuhi bukan karena laba dan sejenisnya, tetapi karena kekurangan kas. Oleh karenanya, penting bagi kita untuk menganalisis kemampuan arus kas dari perusahaan untuk melayani utang (dan beban keuangan lainnya). Sehingga time interest earned dapat diproyeksikan dengan rumus:

$$
\text { Time Interest Earned }=\frac{\text { Laba Sebelum Bunga dan Pajak }}{\text { Beban Bunga }}
$$

\section{Pengembangan Hipotesis}

\section{Pengaruh Profitabilitas terhadap Peringkat Obligasi}

Provitabilitas yang memberikan hasil positif signifikan terhadap peringkat obligasi, hal ini karena perusahaan dinilai mampu menghasilkan laba dengan memperhatikan tingkat penjualan, asset dan modal yang dimiliki oleh perusahaan (Febriani, 2017).

\section{Pengaruh Leverage terhadap Peringkat Obligasi}

Leverage yang memberikan hasil negatif signifikan terhadap peringkat obligasi, hal ini terjadi kerena perusahaan memiliki kemampuan yang rendah untuk melunasi kewajiban kewajibannya sehingga menyebabkan perusahaan dihadapkan pada risiko gagal bayar (Pinandhita and Suryantini, 2016).

\section{Pengaruh Coverage terhadap Peringkat Obligasi}

Coverage dapat juga digunakan untuk melihat apakah sebuah obligasi itu memiliki peringkat yang sesuai atau tidak. Maharani (2018) menemukan bahwa rasio coverage ini memberikan dampak yang positif signifikan bagi peringkat obligasi, hal ini terjadi karena perusahaan dinilai mampu mengelola dana dan memanfaatkannya dengan baik sehingga perusahaan memiliki kemampuan untuk membayar semua kewajibannya tepat pada waktunya.

\section{METODE PENELITIAN}

Penelitian meggunakan data sekunder yang menggunakan data perusahaan disektor perbankan yang terdaftar di BEI dan PT Pefindo dengan jumlah sampel 10 perusahaan. Teknik pengambilan sampel adalah purposive sampling. 


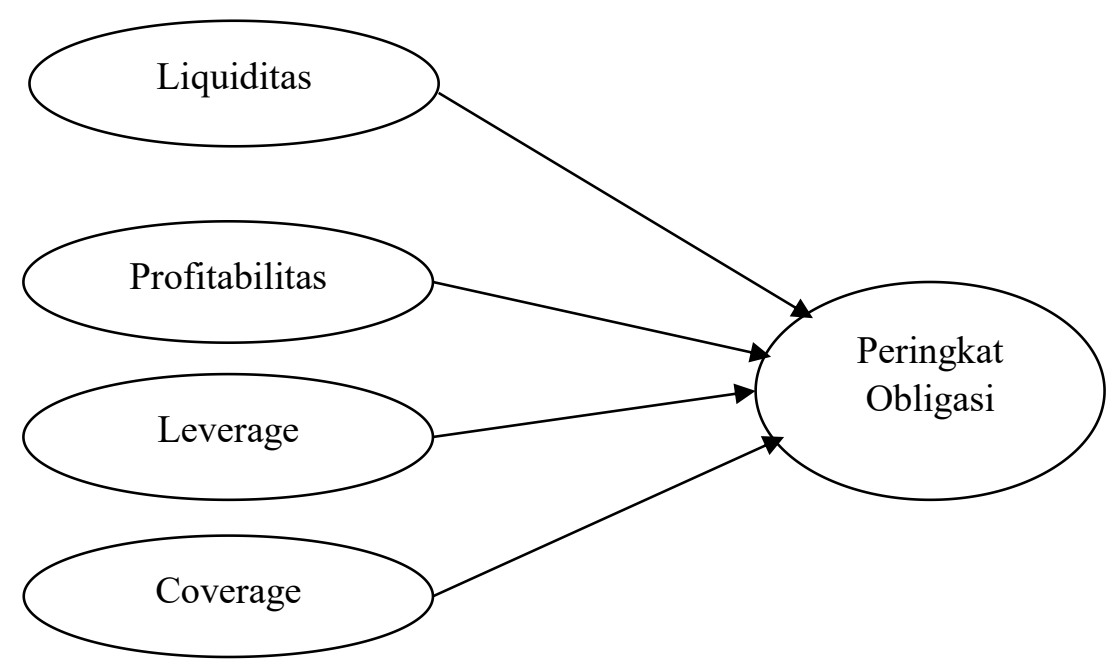

Gambar 1 Kerangka Pikir

\section{HASIL DAN PEMBAHASAN}

\section{Analisis Deskriptif}

Tabel 1 Tabel Distribusi Peringkat Obligasi Peringkat Obligasi

\begin{tabular}{llrrrr}
\hline & Frequency & \multicolumn{1}{c}{ Percent } & Valid Percent & Cumulative Percent \\
\hline \multirow{4}{*}{ Valid } & 21 & 42.0 & 42.0 & 42.0 \\
& Low Investment & & & & 100.0 \\
& High Investment & 29 & 58.0 & 58.0 & \\
\hline & Total & 50 & 100.0 & 100.0 & \\
\hline
\end{tabular}

Sumber: Data Sekunder diolah, 2019

Dari 50 sampel perusahaan yang diteliti, terdapat 21 perusahaan sampel perbankan yang menerima peringkat obligasi dengan kategori low investment grade atau $42 \%$ dari total sampel, sedangkan sisanya sebanyak 29 (58\%) sampel perusahaan menerima peringkat obligasi dengan kategori high investment grade.

\section{Likuiditas}

Tabel 2 Hasil Statistik Deskriptif CR

\begin{tabular}{lccrrr}
\hline \multicolumn{5}{c}{ Descriptive Statistics } \\
\hline & N & Minimum & Maximum & Mean & Std. Deviation \\
\hline CR & 50 & .13 & .46 & .2316 & .05250 \\
Valid N (listwise) & 50 & & & & \\
\hline
\end{tabular}

Sumber: Data Sekunder diolah, 2019

Berdasarkan tabel hasil statistik deskriptif maka dapat dilihat bahwa nilai minimum liquiditas yang diukur dengan current ratio (CR) sebesar 0,13 dan nilai maksimum sebesar 0,46 . Hal tersebut menunjukkan besarnya current ratio pada perusahaan perbankan yang menjadi sampel dalam penelitian ini mulai dari 0,13 sampai 0,46 . Untuk nilai rata-rata sebesar 0,2316 pada standar deviasi 0,525 , dengan begitu nilai rata-rata lebih besar dari standar deviasi yaitu $0,2316>0,525$. Dapat diketahui bahwa current ratio tertinggi terjadi pada perusahaan PT Bank Himpunan Saudara 1906, Tbk. (SDRA) sebesar 0,46, sedangkan untuk current ratio terendah terjadi pada perusahaan PT Bank Tabungan Negara (Persero), Tbk. (BTNG) sebesar 0,13. 


\section{Profitabilitas}

Tabel 3 Hasil Statistik Deskriptif ROA

\begin{tabular}{lccccr}
\hline \multicolumn{5}{c}{ Descriptive Statistics } \\
\hline & N & Minimum & Maximum & Mean & Std. Deviation \\
\hline ROA & 50 & .13 & 3.02 & 1.3728 & .62290 \\
Valid N (listwise) & 50 & & & & \\
\hline
\end{tabular}

Sumber: Data Sekunder diolah, 2019

Berdasarkan tabel hasil statistik deskriptif maka dapat dilihat bahwa nilai minimum profitabilitas yang diukur dengan return on asset (ROA) sebesar 0,13 dan nilai maksimum sebesar 3,02. Hal tersebut menunjukkan besarnya return on asset pada perusahaan perbankan yang menjadi sampel dalam penelitian ini mulai dari 0,13 sampai 3,02. Untuk nilai rata-rata sebesar 1,3728 pada standar deviasi 0,6229, dengan begitu nilai rata-rata lebih besar dari standar deviasi yaitu 1,3728 > 0,6229. Dapat diketahui bahwa return on asset tertinggi terjadi pada perusahaan PT Bank Rakyat Indonesia (Persero), Tbk. (BBRI) sebesar 3,02, sedangkan untuk return on asset terendah sebesar 0,13 terjadi pada PT Bank Bukopin, Tbk (BBKP).

\section{Leverage}

Tabel 4 Hasil Statistik Deskriptif DER

\begin{tabular}{lccccr}
\hline \multicolumn{5}{c}{ Descriptive Statistics } \\
\hline & $\mathrm{N}$ & \multicolumn{1}{c}{ Minimum } & Maximum & Mean & Std. Deviation \\
\hline DER & 50 & .06 & 14.75 & 6.4194 & 2.99279 \\
Valid N (listwise) & 50 & & & & \\
\hline Sul & & & &
\end{tabular}

Sumber: Data Sekunder diolah, 2019

Berdasarkan tabel hasil statistik deskriptif maka dapat dilihat bahwa nilai minimum leverage yang diukur dengan debt to equity ratio (DER) sebesar 0,06 dan nilai maksimum sebesar 14,75. Hal tersebut menunjukkan besarnya debt to equity ratio pada perusahaan perbankan yang menjadi sampel dalam penelitian ini mulai dari 0,06 sampai 14,75 . Untuk nilai rata-rata sebesar 6,4194 pada standar deviasi 2.99279, dengan begitu nilai rata-rata lebih besar dari standar deviasi yaitu $6,4194<2.99279$. Dapat diketahui bahwa debt to equity ratio tertinggi terjadi pada perusahaan PT Bank Bukopin, Tbk (BBKP) sebesar 14,75, sedangkan untuk debt to equity ratio terendah terjadi pada perusahaan PT Bank Pan Indonesia, Tbk. (PNBN) sebesar 0,06.

\section{Coverage}

Tabel 5 Hasil Analisis Deskriptif TIE

\begin{tabular}{lcrrrr}
\hline \multicolumn{5}{c}{ Descriptive Statistics } \\
\hline & $\mathrm{N}$ & \multicolumn{1}{c}{ Minimum } & Maximum & Mean & Std. Deviation \\
\hline TIE & 50 & .70 & 6.21 & 1.6674 & .80706 \\
Valid N (listwise) & 50 & & & & \\
\hline Sum
\end{tabular}

Sumber: Data Sekunder diolah, 2019

Berdasarkan tabel hasil statistik deskriptif maka dapat dilihat bahwa nilai minimum coverage yang diukur dengan time interested earned (TIE) sebesar 0,70 dan nilai maksimum sebesar 6,21. Hal tersebut menunjukkan besarnya time interested earned ratio pada perusahaan perbankan yang menjadi sampel dalam penelitian ini mulai dari 0,70 sampai 6,21. Untuk nilai rata-rata sebesar 1.6674 pada standar deviasi 0.80706 , dengan begitu nilai ratarata lebih besar dari standar deviasi yaitu $1.6674<0.80706$. Dapat diketahui bahwa time interested earned tertinggi terjadi pada perusahaan PT Bank Himpunan Saudara 1906, Tbk. (SDRA) sebesar 6,21, sedangkan untuk time interested earned terendah terjadi pada perusahaan PT Bank OCBC NISP, Tbk. (NISP) sebesar 0,70. 


\section{Model Regresi}

Dalam penelitian ini metode analisis data yang digunakan adalah logistic regression dengan pengolahan data melalui software SPSS (Statistical Package for Social Science). Model ini digunakan untuk melihat apakah ada pengaruh variabel independen terhadap variabel dependen yang berbentuk dikotomi atau variabel biner (Wiyono, 2011), karena variabel dependen yang digunakan berupa variabel dummy (peringkat obligasi kategori high investment grade $=$ satu dan peringkat obligasi kategori low investment grade $=$ nol). Mengingat data dependen variabel model regresi logistik menggunakan data kategorik, maka persyaratan dan asumsi model tidak seketat regresi lainnya. Meskipun demikian, seluruh syarat pembuatan regresi harus tetap ada dalam model regresi logistik. Sebaliknya, pada asumsi dasar dan asumsi klasik lebih diperlonggar karena hanya pada variabel murni saja dilakukan penelitian ini (Gani \& Amalia 2015).

Kelayakan model regresi dinilai dengan menggunakan Hosmer and Lemeshow's Goodness of Fit Test. Model ini untuk menguji hipotesis nol bahwa data empiris sesuai dengan model (tidak ada perbedaaan antara model dengan data sehingga model dapat dikatakan fit).

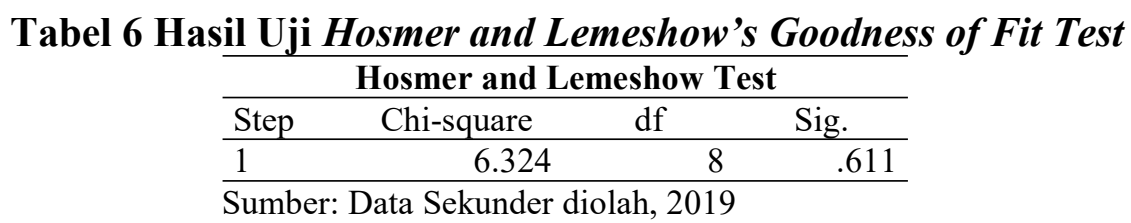

Berdasarkan hasil uji Hosmer and Lemeshow's Goodness of Fit Test diatas dapat disimpulkan bahwa $\mathrm{H}_{0}$ diterima, artinya model mampu memprediksi nilai observasinya atau dapat dikatakan bahwa model dapat diterima karena cocok dengan data observasinya hal ini terlihat dari nilai signifikan sebesar 0,611 yang nilainya jauh diatas 0,05 dan nilai Hosmer and Lemeshow's Goodness of Fit Test sebesar 6,324.

\section{Model Fit}

Uji ini digunakan untuk menilai kesesuaian model yang telah dihipotesiskan dengan data dengan cara membandingkan -2LogL awal dengan nilai -2LogL pada langkah berikutnya.

Tabel 7 Model Fit 1

\begin{tabular}{|c|c|c|c|}
\hline \multicolumn{4}{|c|}{ Iteration History $^{\mathbf{a}, \mathbf{b}, \mathbf{c}}$} \\
\hline \multirow{2}{*}{\multicolumn{2}{|c|}{ Iteration }} & $-2 \log$ & Coefficients \\
\hline & & 11кенпооо & Constant \\
\hline \multirow{3}{*}{ Step 0} & 1 & 68.029 & .320 \\
\hline & 2 & 68.029 & .323 \\
\hline & 3 & 68.029 & .323 \\
\hline
\end{tabular}

a. Constant is included in the model.

b. Initial -2 Log Likelihood: 68.029

c. Estimation terminated at iteration number 3 because parameter estimates changed by less than .001.

Sumber: Data Sekunder diolah, 2019

Pada tabel ini menunjukkan bahwa nilai statistik 2 Log Likehood (block number $=0$ ) tanpa variabel, hanya konstanta aja yaitu sebesar 68,029. Hal ini bisa dikatakan bahwa model tanpa variabel tidak fit. 
Tabel 8 Model Fit 2

\begin{tabular}{|c|c|c|c|c|c|c|c|}
\hline \multicolumn{8}{|c|}{ Iteration History ${ }^{\mathrm{a}, \mathrm{b}, \mathrm{c}, \mathrm{d}}$} \\
\hline \multirow{2}{*}{\multicolumn{2}{|c|}{ Iteration }} & \multirow{2}{*}{$\begin{array}{c}-2 \text { Log } \\
\text { likelihood }\end{array}$} & \multicolumn{5}{|c|}{ Coefficients } \\
\hline & & & Constant & $\mathrm{X} 1$ & $\mathrm{X} 2$ & $\mathrm{X} 3$ & $\mathrm{X} 4$ \\
\hline \multirow{5}{*}{ Step 1} & 1 & 58.286 & -2.054 & 2.666 & 1.257 & -.004 & .033 \\
\hline & 2 & 57.385 & -3.007 & 3.482 & 1.766 & .014 & .080 \\
\hline & 3 & 57.341 & -3.266 & 3.623 & 1.914 & .019 & .095 \\
\hline & 4 & 57.341 & -3.282 & 3.629 & 1.923 & .020 & .096 \\
\hline & 5 & 57.341 & -3.282 & 3.629 & 1.923 & .020 & .096 \\
\hline
\end{tabular}

a. Method: Enter

b. Constant is included in the model.

c. Initial -2 Log Likelihood: 68.029

d. Estimation terminated at iteration number 5 because parameter estimates changed by less than 001 .

Sumber: Data Sekunder diolah, 2019

Setelah dimasukkan keempat variabel independen, maka nilai -2Likelihood akhir mengalami penurunan menjadi sebesar 57,341. Penurunan nilai -2Likelihood ini menunjukkan penambahan variabel independen kedalam model dapat memperbaiki model sehingga model dikatakan fit.

\section{Koefisien Determinasi (Nagelkerke R Square)}

Besarnya nilai koefisien determinasi pada model regresi logistik ditunjukkan dengan nilai Nagelkerke R square. Nilai Nagelkerke R square menghasilkan nilai sebesar 0,259, artinya variabilitas variabel dependen yang dapat dijelaskan oleh variabilitas variabel independen adalah sebesar $25,9 \%$, sedangkan sisanya dijelaskan oleh variabel-variabel lain di luar model penelitian.

Tabel 9 Hasil Uji Nagelkerke R Square

\begin{tabular}{|c|c|c|c|}
\hline \multicolumn{4}{|c|}{ Model Summary } \\
\hline Step & -2 Log likelihood & Cox \& Snell R Square & Nagelkerke R Square \\
\hline 1 & $57.341^{\mathrm{a}}$ & .192 & .259 \\
\hline
\end{tabular}

\section{Uji Omnibus Test of Model Coefficient}

Berdasarkan hasil uji Omnibus Test of Model Coefficient diatas dapat disimpulkan bahwa $\mathrm{H}_{0}$ ditolak, artinya dengan memasukkan variabel independen ke dalam model akan menambah kemampuan prediksi model regresi logistik, hal ini terlihat dari nilai $\mathrm{P}_{\text {value }}$ sebesar 0,030 yang nilainya masih dibawah $0,05\left(\mathrm{P}_{\text {value }}<0,05\right)$ dan nilai Chi-Square sebesar 10,688 dengan derajad kebebasan $(\mathrm{df})=4$

\begin{tabular}{llccc} 
Tabel 1 Hasil Uji Omnibus Test of Model Coefficient \\
\multicolumn{5}{c}{ Omnibus Tests of Model Coefficients } \\
\hline & Chi-square & df & Sig. \\
\hline \multirow{2}{*}{ Step 1 } & Step & 10.688 & 4 & .030 \\
& Block & 10.688 & 4 & .030 \\
& Model & 10.688 & 4 & .030 \\
\hline
\end{tabular}

Sumber: Data Sekunder diolah, 2019

\section{Uji Regresi Logistik Biner}

Uji regresi logistic biner adalah untuk melihat apakah ada pengaruh variabel independen terhadap variabel dependen yang berbentuk dikotomi atau variabel biner. Persamaan regresi 
logistik biner dapat dinyatakan sebagai berikut:

$$
\operatorname{Ln} \frac{P}{(1-P)}=\alpha+\beta 1 \mathrm{LIK}+\beta 2 \mathrm{PROF}+\beta 3 \mathrm{LEV}+\beta 4 \mathrm{COV}+\varepsilon i
$$

Berikut hasil uji regresi logistik biner dengan menggunakan SPSS:

Tabel 2 Hasil Uji Regresi Logistik Biner

\begin{tabular}{|c|c|c|c|c|c|c|c|c|c|}
\hline \multicolumn{10}{|c|}{ Variables in the Equation } \\
\hline & & \multirow[t]{2}{*}{ B } & \multirow[t]{2}{*}{ S.E. } & \multirow[t]{2}{*}{ Wald } & \multirow[t]{2}{*}{$\mathrm{df}$} & \multirow[t]{2}{*}{ Sig. } & \multirow[t]{2}{*}{$\operatorname{Exp}(B)$} & \multicolumn{2}{|c|}{ 95\% C.I.for $\mathrm{EXP}(\mathrm{B})$} \\
\hline & & & & & & & & Lower & Upper \\
\hline \multirow{5}{*}{ Step $1^{\mathrm{a}}$} & $\mathrm{X} 1$ & 3.629 & 6.467 & .315 & 1 & .575 & 37.677 & .000 & 12040571.677 \\
\hline & $\mathrm{X} 2$ & 1.923 & .818 & 5.524 & 1 & .019 & 6.844 & 1.376 & 34.033 \\
\hline & $\mathrm{X} 3$ & .020 & .113 & .030 & 1 & .863 & 1.020 & .817 & 1.273 \\
\hline & $\mathrm{X} 4$ & .096 & .387 & .061 & 1 & .804 & 1.101 & .515 & 2.351 \\
\hline & Constant & -3.282 & 2.209 & 2.208 & 1 & .137 & .038 & & \\
\hline
\end{tabular}

a. Variable(s) entered on step 1: X1, X2, X3, X4.

Sumber: Data Sekunder diolah, 2019

Berdasarkan hasil uji regresi logistik biner, maka persamaan regresi logistik biner, yaitu sebagai berikut:

$$
\operatorname{Ln} \frac{P}{(1-P)}=-3,282+3,629 \mathrm{CR}+1,923 \mathrm{ROA}+0,020 \mathrm{DER}+0,96 \mathrm{TIE}+\varepsilon i
$$

Dari persamaan tersebut dapat dijelaskan sebagai berikut :

1. Konstantan sebesar $-3,282$ menjelaskan bahwa jika seluruh variabel independen konstan (tetap) atau nilainya sama dengan 0 , maka besar tingkat peringkat obligasi sebesar -3,282.

2. Variabel liquiditas yang diukur dengan current ratio (X1) memperoleh nilai koefisien sebesar 3,629. Artinya jika variabel current ratio mengalami peningkatan sebesar 1\%, maka peringkat obligasi perusahaan perbankan akan mengalami peningkatan sebesar 3,629 dengan asumsi variabel independen lainnya dalam kondisi tetap.

3. Variabel profitabilitas yang diukur dengan return on asset (X2) memperoleh nilai koefisien sebesar 1,923. Artinya jika variabel return on asset mengalami peningkatan sebesar $1 \%$, maka peringkat obligasi perusahaan perbankan akan mengalami kenaikan sebesar 1,923 dengan asumsi variabel independen lainnya dalam kondisi tetap

4. Variabel leverage yang diukur dengan debt to equity ratio (X3) memperoleh nilai koefisien sebesar 0,020 . Artinya jika variabel debt to equity ratio mengalami peningkatan sebesar $1 \%$, maka peringkat obligasi perusahaan perbankan akan mengalami peningkatan sebesar 0,020 dengan asumsi variabel independen lainnya dalam kondisi tetap.

5. Variabel coverage yang diukur dengan time interested earned (X4) memperoleh nilai koefisien sebesar 0,96. Artinya jika variabel return on asset mengalami peningkatan sebesar $1 \%$, maka peringkat obligasi perusahaan perbankan akan mengalami peningkatan sebesar 0,96 dengan asumsi variabel independen lainnya dalam kondisi tetap.

Tabel 3 Hasil Uji Hipotesis

\begin{tabular}{lccc}
\hline \multicolumn{1}{c}{ Hipotesis } & $(\beta)$ & Sig & Keterangan \\
\hline $\begin{array}{l}\text { Hipotesis 1 : Likiuditas berpengaruh positif } \\
\text { terhadap peringkat obligasi. }\end{array}$ & 3,629 & 0,575 & Diterima \\
\hline $\begin{array}{l}\text { Hipotesis 2 : Profitabilitas berpengaruh positif } \\
\text { terhadap peringkat obligasi. }\end{array}$ & 1,923 & 0,19 & Diterima \\
\hline $\begin{array}{l}\text { Hipotesis 3 : Leverage berpengaruh negatif } \\
\text { terhadap peringkat obligasi. }\end{array}$ & 0,020 & 0,863 & Ditolak \\
\hline $\begin{array}{l}\text { Hipotesis 4 : Coverage berpengaruh positif } \\
\text { terhadap peringkat obligasi. }\end{array}$ & 0,096 & 0,804 & Diterima \\
\hline $\begin{array}{l}\text { Sumber: Data Sekunder diolah, 2019 } \\
\text { Sumber }\end{array}$ & & &
\end{tabular}


1. Pengaruh Likiuditas terhadap peringkat obligasi

Berdasarkan hasil uji diperoleh nilai koefisien sebesar 3,629. Variabel likiuditas yang diukur dengan current ratio signifikansi sebesar 0,575. Hal tersebut menunjukan bahwa nilai signifikansi lebih besar dari 0,05 , maka variabel likiuditas yang diukur dengan current ratio berpengaruh positif namun tidak signifikan terhadap peringkat obligasi pada perusahaan perbankan yang terdaftar di BEI selama periode 2014 sampai 2018, penelitian ini selaras dengan (Kurniawan, 2016) dengan hasil uji yang diperoleh dengan nilai signifikansi 0,147 lebih besar dari 0,05 yang berarti likuiditas tidak berpengaruh secara signifikan terhadap peringkat obligasi perusahaan.

2. Pengaruh Profitabilitas terhadap peringkat obligasi

Berdasarkan hasil uji diperoleh nilai koefisien sebesar 1,923. Variabel profitabilitas yang diukur dengan return on asset mempunyai signifikansi sebesar 0,19. Hal tersebut menunjukan bahwa nilai signifikansi lebih kecil dari 0,05, maka variabel profitabilitas yang diukur dengan return on asset berpengaruh positif dan signifikan terhadap peringkat obligasi pada perusahaan perbankan yang terdaftar di BEI selama periode 2014 sampai 2018 hal ini selaras dengan penelitian yang dilakukan oleh (Febriani, 2017) dengan hasil uji nilai koefisien regresi sebesar 1,169 dan nilai signifikansi $0,020<$ 0,05 .

3. Pengaruh Leverage terhadap peringkat obligasi

Berdasarkan hasil uji diperoleh nilai koefisien sebesar 0,020. Variabel leverage yang diukur dengan debt to equity ratio mempunyai signifikansi sebesar 0,863 . Hal tersebut menunjukan bahwa nilai signifikansi lebih besar dari 0,05 , maka variabel leverage yang diukur dengan debt to equity ratio berpengaruh positif namun tidak signifikan terhadap peringkat obligasi pada perusahaan perbankan yang terdaftar di BEI selama periode 2014 sampai 2018. Penelitian ini selaras dengan Sari \& Bardja (2016) dengan hasil uji nilai koefisien regresi variabel leverage perusahaan yang diukur dengan rasio Debt to Equity Ratio (DER) adalah sebesar 0,170 dengan tingkat signifikansi sebesar 0,598 .

4. Pengaruh Coverage terhadap peringkat obligasi

Berdasarkan hasil uji diperoleh nilai koefisien sebesar 0,096. Variabel coverage yang diukur dengan time interested earned mempunyai signifikansi sebesar 0,804 . Hal tersebut menunjukan bahwa nilai signifikansi lebih besar dari 0,05 , maka variabel coverage yang diukur dengan time interested earned tidak berpengaruh dan tidak signifikan terhadap peringkat obligasi pada perusahaan perbankan yang terdaftar di BEI selama periode 2014 sampai 2018. Penelitian ini selaras dengan Syawal (2016) dengan hasil uji interest coverage ratio menunjukkan koefisien positif sebesar 0.901 dan dengan tingkat signifikansi sebesar 0,240 sehingga pengaruhnya tidak signifikan.

\section{PENUTUP}

Berdasarkan penelitian yang telah dianalisis, maka ditarik kesimpulan sebagai berikut:

1. Likuditas yang diukur dengan current ratio berpengaruh positif namun tidak signifikan terhadap peringkat obligasi pada perusahaan perbankan periode 2014 - 2018. Hal tersebut ditunjukan dengan tingkat signifikansi sebesar 0,575 dan nilai koefisien yang bernilai positif sebesar 3,629. Sehingga likuditas yang diukur dengan current ratio masih belum dapat digunakan dengan baik untuk memprediksi peringkat obligasi.

2. Profitabilitas yang diukur dengan return on asset berpengaruh positif dan signifikan terhadap peringkat obligasi pada perusahaan perbankan periode 2014 - 2018. Hal 
tersebut ditunjukan dengan tingkat signifikansi sebesar 0,19 dan nilai koefisien yang bernilai positif sebesar 1,923. Sehingga profitabilitas yang diukur dengan return on asset dapat memprediksi peringkat obligasi dengan baik.

3. Leverage yang diukur dengan debt to equity ratio berpengaruh positif namun tidak signifikan terhadap peringkat obligasi pada perusahaan perbankan periode 2015 - 2018 . Hal tersebut ditunjukan dengan tingkat signifikansi sebesar 0,863 dan nilai koefisien yang bernilai positif sebesar 0,20 . Sehingga leverage yangdiukur dengan debt to equity ratio masih belum dapat digunakan dengan baik untuk memprediksi peringkat obligasi.

4. Coverage yang diukur dengan interest coverage ratio berpengaruh positif namun tidak signifikan terhadap peringkat obligasi pada perusahaan perbankan periode $2014-2018$. Hal tersebut ditunjukan dengan tingkat signifikansi sebesar 0,804 dan nilai koefisiesn yang bernilai positif sebsar 0,096. Sehingga coverage yang diukur dengan interest coverage ratio masih belum dapat digunakan dengan baik untuk memprediksi peringkat obligasi.

Berdasarkan hasil penelitian, maka diajukan saran - saran sebagai berikut:

1. Bagi peneliti selanjutnya bisa menambah variabel yang dapat mempengaruhi peringkat obligasi karena dapat dilihat masih sebesar $74,1 \%$ pengaruh dari variabel diluar penelitian ini. Peneliti selanjutnya sabaiknya juga menambah jumlah variabel dan sampel.

2. Bagi investor yang akan menginvestasikan dananya dalam bentuk obligasi hendaknya memerhatikan peringkat obligasi perusahaan yang bersangkutan, karena peringkat tersebut menggambarkan kinerja keuangan perusahaan.

3. Bagi emiten hendaknya memperbaiki atau meningkatkan kinerja keuangannya. Dengan meningkatkan kinerja keuangan perusahaan maka akan mengakibatkan peringkat obligasi yang baik, sehingga akan berdampak pada daya jual perusahaan yang tinggi.

\section{DAFTAR PUSTAKA}

Darmadji, Tjiptono, Hendy M Fakhruddin. 2012. Pasar Modal Indonesia. Jakarta: Salemba Empat.

Febriani, Anita. 2017. "Pengaruh Likuiditas, Profitabilitas, Leverage Dan Audit Tenure Terhadap Peringkat Obligasi."

Gani, Irwan, Siti Amalia. 2015. Alat Analisis Data: Aplikasi Statistik Untuk Penelitian Bidang Ekonomi Dan Sosial. Yogyakarta: CV Andi Offset.

Hanafi, Mamduh, Abdul Halim. 2016. Analisis Laporan Keuangan. Yogyakarta: UPP STIM YKPN.

Hery. 2015. Analisis Kinerja Manajemen. Jakarta: PT Grasindo.

Horne, James C. Van, John M. Wachowicz. 2017. Prinsip - Prinsip Manajemen Keuangan. Jakarta: Salemba Empat.

Kurniawan, Dian Wahyu. 2016. "Kemampuan Rasio Keuangan Untuk Memprediksi Peringkat Obligasi Perusahaan Non Jasa Keuangan Yang Terdaftar Di Bursa Efek Indonesia."

Maharani, Fatiha Rachmalita. 2018. "Pengaruh Rasio Leverage, Interest Coverage Ratio Dan Jaminan Terhadap Peringkat Obligasi Perusahaan Bumn Bidang Konstruksi Yang Terdaftar Di Bursa Efek Indonesia Tahun 2012-2016."

Pinandhita, Adi Wira, and Ni Putu Santi Suryantini. 2016. "Pengaruh Profitabilitas, Rasio Solvabilitas, Ukuran Perusahaan Dan Reputasi Auditor Terhadap Peringkat Obligasi Pada Sektor Perbankan."

Sari, Ni Made Sri Kristina, Ida Bagus Bardja. 2016. "Pengaruh Likuiditas , Ukuran Perusahaan , Leverage Dan Jaminan Terhadap Peringkat Obligasi Pada Sektor Keuangan." 5(8): 5041-69. 
Syawal, Teuku Muhammad. 2016. "Pengaruh Profitabilitas , Interest Coverage Ratio , Retained Earning Dan Pertumbuhan Perusahaan Terhadap Peringkat Obligasi Pada Perusahaan Non Keuangan Yang Terdaftar Di Bursa Efek Indonesia Tahun 2012-2014." 1(2): 237-51.

Wiyono, Gendro. 2011. 3 in One Merancang Penelitian Bisnis Dengan Alat Analisis SPSS17.0 \& SmartPLS 2.0. Yogyakarta: UPP STIM YKPN. 